Article

\title{
Dispute Settlement for Labour Provisions in EU Free Trade Agreements: Rethinking Current Approaches
}

\author{
Axel Marx ${ }^{1, *}$, Franz Ebert ${ }^{2}$ and Nicolas Hachez ${ }^{1}$ \\ ${ }^{1}$ Leuven Centre for Global Governance Studies, KU Leuven, 3000 Leuven, Belgium; E-Mails: axel.marx@kuleuven.be (A.M.), \\ nicolas.hachez@kuleuven.be (N.H.) \\ 2 Max Planck Institute for Comparative Public Law and International Law, 69120 Heidelberg, Germany; \\ E-Mail: ebert@mpil.de \\ * Corresponding author
}

Submitted: 19 June 2017 | Accepted: 3 November 2017 | Published: 14 December 2017

\begin{abstract}
While labour provisions have been inserted in a number of EU free trade agreements (FTAs), extant clauses are widely perceived as ineffective. This article argues that there is a need to rethink the dispute settlement mechanisms related to labour provisions if their effectiveness is to be increased. It proceeds in three steps. First, we look at the current state of the art of labour provisions in EU FTAs in terms of legal design and practice and argue that the current arrangements are ill-equipped to foster compliance with labour standards. Second, we explore avenues to enhance the design of FTA labour provisions by reconsidering basic elements of the dispute settlement structure. Examining US FTA labour provisions, we highlight the importance of a formal complaint mechanism, on the one hand, and the availability of economic sanctions, on the other. Based on a review of existing practice, we contend, however, that these elements alone are not sufficient to effectively enforce FTA labour provisions. We argue that for FTA labour provisions to be effective, the current stateto-state model of dispute settlement needs to be complemented by a third-party-state dimension and that, additionally, there are good reasons to consider a third party-third party dispute settlement component. We ground these reflections in experiences with already existing instruments in other areas, namely investor-state dispute settlement and voluntary sustainability standards. Thirdly, we discuss options to better connect the dispute settlement mechanisms of FTA labour provisions to other international instruments for labour standards protection with a view to creating synergies and avoiding fragmentation between the different regimes. The focus here is on the International Labour Organization's supervisory mechanism and the framework of the OECD Guidelines for Multinational Enterprises.
\end{abstract}

\section{Keywords}

EU; labour rights; trade agreements; trade policy

\section{Issue}

This article is part of the issue "Labour Standards in a Global Environment", edited by Gerda Van Roozendaal (University of Groningen, The Netherlands) and Jan Orbie (Ghent University, Belgium).

(C) 2017 by the authors; licensee Cogitatio (Lisbon, Portugal). This article is licensed under a Creative Commons Attribution 4.0 International License (CC BY).

\section{Introduction}

The protection of labour standards has become a fixture in free trade agreements (FTAs) concluded by the EU. This corresponds to a more general trend which has seen a steady increase in the number of FTAs including labour provisions since the 1990s (International Labour Organization [ILO], 2009, 2013), counting more than 70 such agreements in 2016 (ILO, 2016, p. 22). However, the provisions concerning labour rights are often regarded as ineffective in terms of actually enforcing labour rights (see e.g. Campling, Harrison, Richardson, \& Smith, 2016; Marx, Lein, \& Brando, 2016; Scheuerman, 2001; Van Roozendaal, 2015; Vogt, 2015). In particular, there is concern that the implementation devices regarding FTA labour provisions might be insufficient to address 
non-compliance in practice (Harrison, Barbu, Campling, Richardson, \& Smith, 2017; Marx \& Soares, 2015; Marx et al., 2016; Orbie \& Van den Putte, 2016). While it is recognized that FTA labour provisions may entail other positive effects, such as increasing labour-related capacity building (Cheong \& Ebert, 2016; Ebert, 2016), there is a growing consensus that the relevant enforcement mechanisms, notably the arrangements for dispute settlement, are unsuitable to significantly foster compliance with labour rights (see e.g. Ebert, 2017; Scheuerman, 2001; Vogt, 2015).

In this article, we investigate how the institutional design relating to labour provisions in FTAs can be improved to foster better compliance, focusing on the role of dispute settlement mechanisms. This focus emerges in a wider academic debate in which the empowerment of stakeholders to enforce compliance with international rules is emphasized. We assume that the integration of viable dispute settlement mechanisms into the labour provisions of FTAs can strengthen enforcement and compliance. This can occur either through the threat of a possible dispute and the consequences that may come with it (anticipatory effect) or through the dispute settlement process proper, which may generate dynamics inducing compliance, for example through the application of economic sanctions or political pressure. This assumption is grounded in theoretical and empirical literature in institutional economics, political science, and public policy (see e.g. Ostrom, 2005). This literature suggests that robust monitoring and sanctioning systems are necessary conditions for ensuring compliance with rules. In addition, international law scholarship refers to the importance of establishing a well-developed set of rules and procedures to foster compliance with international rules, although with less emphasis on disputes and sanctioning. This scholarship stresses that enforcement of international rules requires a set of procedures and mechanisms which implement (see e.g. the managerial approach put forward by Chayes \& Handler Chayes, 1995) or internalize international legal rules in the domestic legal system (see e.g. Koh, 1997). Both theories stress the importance of interactions between actors and mechanisms which allow for interaction, for complying with international rules.

Against this background, this article contributes to the wider theoretical ambitions of this thematic issue by focusing on an additional element of effectiveness, namely institutional design effectiveness. As Niemann and Bretherton (2013, p. 267) note, the concept of effectiveness is notoriously difficult to define and measure. The editors of this thematic issue start from a traditional conceptualization of impact and effectiveness which is more aligned with a focus on goal-attainment effectiveness (Conceição-Heldt \& Meunier, 2014). Goalattainment effectiveness in the context of FTAs can be seen as an actor's 'ability to realise the goals they set for themselves' (Acharya \& Johnston, 2007, p. 13) or the EU's ability to reach its objectives by influencing other actors (Van Schaik, 2013). However, before goals can be achieved one needs to build institutions which facilitate the achievement of these goals. In this way, institutional effectiveness presupposes goal-attainment effectiveness. Institutional effectiveness builds on the work of Elinor Ostrom (2005) and assesses whether the design of FTAs is effective. For example, FTAs with extensive rules and procedures (that is, institutions) on enforcement, monitoring, dispute settlement, and sanctioning are hypothesised to be more effective in achieving their objectives. In this light, we seek to explore how the institutional design of FTAs can be strengthened by analysing the deficiencies of the current approaches.

The article proceeds in three steps. First, we look at the current state of the art of labour provisions in EU FTAs in terms of legal design and practice. We show that the existing mechanisms are subject to significant deficits that limit their potential to foster labour rights implementation. Second, we explore avenues to enhance the design of FTA labour provisions by reconsidering basic elements of the dispute settlement structure. Examining US FTA labour provisions, we highlight the importance of a formal complaint mechanism and the availability of economic sanctions. Based on existing practice, we contend, however, that these elements alone are not sufficient to effectively enforce FTA labour provisions. We argue that for FTA labour provisions to be effective the current state-to-state model of dispute settlement needs to be complemented by a third-party-state dimension and that, additionally, there are good reasons to consider a third party-third party dispute settlement component. We ground these reflections in experiences with already existing instruments in other areas, namely investor-state dispute settlement and voluntary sustainability standards (VSS). Third, we ponder options to better connect FTA labour provisions to other instruments for labour rights protection with a view to creating synergies and avoiding fragmentation between the different regimes. The focus here is on the ILO supervisory mechanism, on the one hand, and the framework of the Organization for Economic Co-operation and Development (OECD) Guidelines for Multinational Enterprises (MNEs), on the other hand. We close by briefly discussing the various alternatives.

\section{The Need to Rethink Extant EU FTA Dispute Settlement Mechanisms for Labour Provisions}

Recent EU FTAs contain various types of commitments. ${ }^{1}$ This typically includes commitments regarding the observance of the ILO Fundamental Conventions, ${ }^{2}$ a commitment to enforce domestic labour laws alongside a com-

\footnotetext{
${ }^{1}$ For an overview see Bartels (2013, pp. 306-308), and ILO (2016, pp. 39-41). Many EU FTAs contain certain additional commitments, e.g. to 'consider the ratification' of other ILO conventions and exchange information in this regard; see e.g. art. 229 (4) of the EU-Georgia Agreement.

${ }^{2}$ See, e.g. art. 269(3) of the EU-Colombia and Peru Agreement; art. 365(2) of the EU-Moldova Agreement.
} 
mitment not to lower domestic labour rights in order to increase levels of trade and investment. ${ }^{3}$ There is also an obligation to monitor and assess the impact of the agreement on sustainable development issues including compliance with labour rights. ${ }^{4}$ EU FTAs furthermore emphasize institutional inter-party dialogue and cooperation and the participation of civil society actors in the monitoring of the parties' compliance with the relevant labour requirements (Postnikov \& Bastiaens, 2014, p. 925).

The monitoring processes agreed upon in the Trade and Sustainable Chapters of EU FTAs (TSD chapters) are twofold. First of all, the general joint committees and councils in charge of overseeing the agreement as a whole, which are typically competent to discuss any matter in relation to the agreement, are also entitled to discuss sustainable development issues. Second, the main innovation of TSD chapters resides in their monitoring by institutions representing civil society actors which are created by the agreement such as 'Domestic Advisory Groups' (DAGs) for each party. Composed of NGOs, business, trade unions, and other experts from relevant stakeholder groups, these groups are supposed to meet on a regular, typically annual basis. ${ }^{5}$ Dialogue at the official level is therefore central, and civil society is an essential actor in the implementation and monitoring of TSD chapters.

Furthermore, EU FTAs provide for a special procedure for labour provisions, including amicable consultations and, subsequently, the review of the issue at stake by an ad-hoc expert body ${ }^{6}$ which can adopt findings and recommendations on the subject matter. ${ }^{7}$ As a followup, the expert body's report is presented to the parties, and the party concerned is typically required to indicate the measures it envisions undertaking with a view to addressing the findings and recommendations of the expert panel. ${ }^{8}$ The implementation of the relevant measures is then monitored by the competent committee or body, as established under the relevant agreement. ${ }^{9}$

The experiences made thus far with dispute settlement mechanisms pertaining to the labour provisions in EU FTAs indicate at best limited potential for enforcing labour rights (see also Marx et al., 2016). A key factor limiting the enforcement leverage of these provisions is the absence of sanctions which makes their implementation to a large extent dependent on the parties' political goodwill. ${ }^{10}$ Furthermore, no case is apparent where the relevant formal consultation mechanisms-let alone the non-sanction-based dispute settlement mechanismshave been activated (see e.g. Ebert, 2017, p. 308). In addition, the absence of a formal complaint mechanism has allowed the European Commission to refrain from an in-depth assessment of labour rights violations raised by civil society actors (see Vogt, 2015, pp. 857-858). ${ }^{11}$ This is not compensated by the dialogue activities conducted under the EU FTAs, either among the state parties or with civil society. Arguably, this can, in part, be attributed to the failure of the European Commission to use political influence to bring about changes regarding labour rights in partner countries (see also Campling et al., 2016, pp. 370-371). As a result, EU partner countries appear to have been rather indifferent to the allegations of relevant civil society actors (Vogt, 2015).

\section{Rethinking the Dispute Settlement Process for Labour Provisions in EU FTAs: Insights from Other Approaches and Instruments}

\subsection{Increasing Enforcement Leverage: The Case of US FTA Labour Provisions}

The approach, notably used by the US and Canada, combines cooperation and enforcement mechanisms, involving, as a last resort, economic sanctions. Under most US FTAs there is a formal procedure under which civil society actors can submit complaints against one country to a designated national office with the Government of another party. ${ }^{12}$ This national office subsequently examines the complaint following an internal procedure and can, where appropriate, make recommendations on how to resolve the problems at hand. The complaints procedure under US FTAs is, hence, significantly more formalized than under those concluded by the EU.

Furthermore, any state party can subsequently initiate ministerial consultations on the matter with the other party ${ }^{13}$ and seek the establishment of an arbitral panel for parts or the entirety of the agreement's labour chapter (ILO, 2009, 2013). The dispute settlement mechanisms for labour provisions under US FTAs have evolved considerably over time. In particular, the scope of the arbitration-based dispute settlement mechanism has been widened from applying only to certain labour provisions $^{14}$ to covering the entire labour chapter. ${ }^{15}$

\footnotetext{
${ }^{3}$ See, e.g. art. 23.4 of the CETA.

${ }^{4}$ See, e.g. art. 293 of the EU-Central America Agreement.

${ }^{5}$ See, e.g. arts. 294-295 of the EU-Central America Agreement.

${ }^{6}$ These are typically referred to as 'panel of experts' or 'group of experts'.

7 See, e.g. art. 13.14 and 13.15 of the EU-Republic of Korea Agreement; art. 283-285 of the EU-Peru and Colombia Agreement.

8 See, e.g. art. 301(3) of the EU-Central America Agreement.

${ }^{9}$ See, e.g. art. 285(4) of the EU-Peru and Colombia Agreement.

10 Evidence suggests that to have some positive effects sanction regimes do not necessarily need to be applied; rather it is often already the credible threat of trade sanctions that can induce compliance (Charnovitz, 2001, p. 809; see also Davey, 2009, p. 124; Lacy \& Niou, 2004).

${ }^{11}$ For a case in point regarding the EU-Korea FTA, see Van den Putte (2015, p. 229).

12 See, e.g. art. 16(3) of the NAALC.

13 See, e.g. art. 22 of the NAALC and of the NAAEC, respectively.

14 See, e.g. arts. 16.6(7) and 17.10(7) of CAFTA-DR.

15 Cf. arts. 17.7, 18.12 and 21.2 of the US-Colombia Trade Agreement.
} 
Also, while most of the earlier US FTAs involve only limited fines which are to be used for remedying the compliance issue at hand, ${ }^{16}$ more recent US FTAs allow for inflicting trade sanctions under the general dispute settlement mechanism. ${ }^{17}$ The enforcement mechanism for labour provisions in US FTAs can thus be considered considerably more vigorous than that of their EU counterparts.

However, the labour provisions contained in US FTAs have so far not proven to be a highly effective enforcement device. In fact, there has been only one labour rights-related case where a dispute settlement procedure under an FTA was set in motion. This dispute, which arose under CAFTA-DR between the US and Guatemala, deals with severe violations of trade union rights in Guatemala. ${ }^{18}$ The scarcity of labour-related disputes in dispute settlement contrasts with the number of complaints that have been filed under some of the agreements. In the area of labour rights, most complaints have been brought under the NAALC, amounting to about 40 complaints between its entry into force in 1994 and 2015. Under other US agreements, eight labour-related complaints were filed with the US Government prior to November 2017. ${ }^{19}$ The bulk of the complaints have so far been terminated or resolved by the competent national offices without even reaching ministerial consultations, let alone dispute settlement stage, and with no evidence that the often-serious alleged violations of the relevant labour provisions were sufficiently addressed. ${ }^{20}$

A key factor accounting for this situation relates to the institutional design of the relevant enforcement mechanisms. First, civil society actors can only file complaints but not activate the dispute settlement procedure against the party complained against, a prerogative that remains reserved for the state parties to the FTAs. Second, US FTAs accord the state parties full discretion as to whether or not to activate the dispute settlement mechanism, to solve the dispute through other means, or to remain inactive. Even if the national office of the party receiving the complaints identifies severe violations of labour provisions of the relevant agreement, that state party is by no means legally compelled to take further action. As a result, the relevant FTA parties have been able to refrain from taking appropriate action even in the face of allegations of serious breaches of the rel- evant labour provisions. While recent US FTAs provide the same dispute settlement mechanism for labour provisions as for the agreements' trade-specific provisions, it turns out that this approach is unsuitable for labour concerns given the parties' widespread disinclination to utilize these arrangements to tackle these matters (Sagar, 2004, p. 948).

\subsection{Providing Direct Access to Dispute Settlement for Third Parties: The Case of Investment Arbitration}

Investment treaties usually allow a foreign investor to sue the host state before an international arbitral tribunal in order to seek remedy for the breach of its treaty-protected rights, such as those regarding nondiscrimination, fair and equitable treatment, or protection against expropriation. Traditionally, investment arbitration is realized through a private and ad hoc tribunal whereby the parties freely choose the arbitrators and the rules of procedure according to a defined model such as that of the International Centre for the Settlement of Disputes (ICSID) or of the UN Conference on International Trade Law (UNCITRAL). These mechanisms are modelled on commercial arbitration and typically do not provide for the possibility of appealing the award. EU investment chapters in the Comprehensive Economic and Trade Agreement between the EU and Canada (CETA) and the EU-Vietnam Free Trade Agreement (EUVFTA) contain a more elaborate 'investment court system' (ICS), ${ }^{21}$ which sets up a permanent tribunal composed of international trade and investment law experts from the EU, the partner country, and third countries, as well as appellate tribunals. Each case is normally heard by three members, one from each category, drawn by lot. ${ }^{22}$

Only investors can file a claim to the ICS. ${ }^{23}$ Concerning access to the proceedings by third parties, both CETA and the EU-Vietnam FTA include the UNCITRAL transparency rules and provide for the publicity of procedural documents and hearings. ${ }^{24}$ Submission of amici curiae briefs is possible. ${ }^{25}$ The other State party may receive the procedural documents and make observations. ${ }^{26}$ ICS is governed by ICSID or UNCITRAL procedural rules or other rules if the parties agree. ${ }^{27}$ The submission of a claim to the tribunal must be preceded by consultations aim-

\footnotetext{
16 See, e.g. art. 20.17 of CAFTA-DR.

17 See, e.g. art. 21.16 of the US-Colombia Trade Agreement.

18 See Final Report of the Panel in the Matter of Guatemala-Issues Relating to the Obligations under Article 16.2.1(a) of the CAFTA-DR of June 14, 2017. In this case, the Panel found that the US had not demonstrated that Guatemala had breached the relevant labour provisions.

${ }^{19}$ For an overview of relevant complaints visit the webpage of the US Department of Labor (Office on Trade and Labor Affairs) at https://www.dol.gov/ agencies/ilab/our-work/trade/fta-submissions. One complaint concerning Costa Rica had been withdrawn after the subject matter at hand had been addressed at the domestic level (ILO, 2013, pp. 51, 55).

${ }^{20}$ For examples regarding cases under the NAALC see Schurtman (2005, pp. 332-333); Compa and Brooks (2015, pp. 63-64). See also Oehri (2017) in this issue.

21 These FTAs are not yet in force or not yet fully in force and the ICS is therefore not yet in operation.

22 See arts. 18.27 and 18.28. CETA; art. 13 EUVFTA.

23 Art. 8.23 (1) CETA, and art. 2 EUVFTA.

24 Art. 8.35 CETA; art. 20 EUVFTA.

25 Art. 4 UNCITRAL Transparency Rules.

26 Art. 8.38 CETA; art. 25 EUVFTA.

27 Art. 8.23 (2) CETA; art. 72 EUVFTA.
} 
ing to amicably settle the dispute. ${ }^{28}$ None of the agreements requires exhaustion of domestic remedies. ${ }^{29}$ The material jurisdiction of ICS is strictly limited to breaches of rights granted to investors by the treaty. ${ }^{30}$ When a breach is found, the only possible outcomes are monetary damages or restitution of property, ${ }^{31}$ but to preserve state sovereignty, in no case may the tribunal annul a state measure or order a positive measure. Costs are normally borne by the unsuccessful party, unless circumstances warrant otherwise. ${ }^{32}$

An ICS-like mechanism may carry some advantages with respect to the enforcement of labour provisions. First, the possibility of offering a binding outcome to private parties and of holding defaulting governments to account may increase the focus on compliance and thereby reduce the politicization of the application of labour provisions (see Gött, in press). Second, investment arbitration is typically more expeditious than judicial remedies, even though the addition of an appeals mechanism may lengthen the proceedings. Third, such a mechanism would also avoid giving the impression that the protection of labour standards is considered by the EU to be less important than investor protection and might contribute to increasing the legitimacy of the EU's trade policy as a whole.

A number of obstacles would, however, have to be overcome if a mechanism modelled on ICS as it currently stands (hereinafter 'ICS-like mechanism'), were to be effectively employed as a way to enforce labour provisions. First, the material jurisdiction of investment tribunals is strictly limited to a few well-defined treaty provisions (see above). Subjecting the more wide-ranging commitments contained in labour provisions to an ICS-like mechanism would significantly expand its scope, thereby increasing the potential number of cases, and requiring the tribunal's breadth of expertise to be more extensive than what is now required of arbitrators.

Second, ICS standing is strictly limited to foreign investors, but labour provisions concern a wider group of third parties, which would require making determinations as to which interests deserve to be granted access. Host states typically grant direct access to an arbitral mechanism because they hope to attract capital and related benefits such as tax revenue, jobs, transfers of technology, knowhow, etc. (Choi, 2007, pp. 732-733). This kind of governmental incentive to provide investors access to an ICS-like mechanism is not as clear in the labour context. Also, potentially affected stakeholders are much more numerous, and ways to limit standing in a fair and non-discriminatory manner would have to be carefully elaborated, for instance by limiting it to representative organisations such as trade unions, employers' organiza- tions, particularly interested civil society organizations, or to a minimal number of claimants grouped together. Additionally, if standing were still to be granted to individuals, it could be limited through the customary requirement of exhausting domestic remedies, which is generally waived in investment arbitration (see also Stoll, Gött, \& Abel, 2017, pp. 39, 41).

Relatedly, standing implies that the claimant may rely on litigable rights, whereas currently TSD chapters partly tend to restate general state commitments, in particular towards ILO Conventions, which may require some rewriting in order to be read, e.g., as standards of treatment, or as commitments to attaining well-defined goals, which would be effectively litigable by third parties. Likewise, state measures lowering social standards for the purpose of attracting trade or investment might be opened to direct challenge. ${ }^{33}$ This, while arguably pursuing the desirable goal of putting labour concerns on an equal footing with economic objectives, would radically alter the balance of the entire agreement, since trade commitments would be matched with directly enforceable social provisions. States would therefore have to consider whether they are willing, in the context of an agreement on trade, to complement labour provisions obligations with such a strong dispute settlement mechanism, whereas they were not willing to do so when they undertook the initial commitment in, e.g., the ILO Conventions linked to the TSD chapters. One way to address this issue could be to limit the scope of enforceable provisions concerning labour rights to a relatively small number of litigable commitments.

Fifth, in terms of remedies sought, ICS can only award monetary damages or order restitution of property. These types of remedies indexed on a commercial logic are less suitable to compensating the breach of labour rights obligations, which often require putting in place long-term strategies and implementing them through a series of measures. Ensuring that these strategies and measures are adopted and implemented is in all likelihood what the claimant in such cases would want to seek, not necessarily monetary damages. Adapting this aspect in an ICS-like mechanism to include the possibility for the tribunal to order measures would, as indicated above, represent another significant inroad into state sovereignty, as it would limit the states' freedom to determine their own levels of domestic protection in the social area, ${ }^{34}$ which they have so far been careful to preserve. The threat of such monetary sanction might, however, be one incentive to foster compliance and change.

A final obstacle which can be identified in relation to ICS, concerns the costs involved in litigating through such a dispute settlement system. The costs are typically

\footnotetext{
${ }^{28}$ Art 8.21 (1) CETA; art. 6 (1) EUVFTA.

${ }^{29}$ Art. 8.22 (1) (f) and (g) CETA; art. 8.1 and 4 (b) EUVFTA

30 Art. 8.18 CETA; art. 1 EUVFTA.

31 Art 8.39 (a) CETA; art. 27 EUVFTA.

32 Art 8.39 (5) CETA; art. 27.4 EUVFTA.

33 See Chapter 16, art. 10 EUVFTA.

34 See Chapter 16, art. 2 EUVFTA.
} 
high (OECD, 2012) and may not be affordable for private parties unless measures are taken to limit them. ${ }^{35}$ This could be done in a number of ways, for instance by capping arbitrator fees; by ensuring that the place of arbitration does not involve excessive travel for the parties (or by working at a distance or through electronic means as much as possible); by setting up a legal aid fund or by waiving the cost of proceedings for vulnerable claimants.

In sum, the main advantage of an ICS-like mechanism would be to enhance the enforcement potential of labour chapters by allowing non-state actors to sue state parties for breaches of their treaty-based rights. However, our examination evidences significant obstacles related to scope, standing, remedies and costs. At the very least-and without pre-judging the political feasibility of such adaptations-in order for an ICS-like mechanism to work in this context, the following aspects would need to be carefully designed: (i) management of the potential number of claims by limiting standing to groups of individuals or by requiring exhaustion of domestic remedies; (ii) precise identification of the kinds of claims which would be admissible before the ICS-like mechanisms, in respect of the labour rights covered and the types of violations alleged; (iii) redress mechanisms that would be compatible with the nature of labour rights; (iv) a cost-model that remains accessible to private individuals or not-for-profit organizations representing labour rights interests.

\subsection{Integrating a Third Party Versus Third Party Dimension into the Dispute Settlement Mechanism: The Example of Voluntary Sustainability Standards}

Another existing initiative that might be considered for the purpose of strengthening enforcement of FTA labour provisions through dispute settlement concerns VSS, also known as sustainability certification schemes and eco-labels (United Nations Forum on Sustainability Standards, 2013). Examples of such VSS include the standards adopted by the Fair Labour Association, the Fair Wear Foundation, and the Forest Stewardship Council (FSC). They involve a collection of organisations that certify producers that adhere to a set of sustainability standards. These standards are developed on the basis of broad principles and commitments which are often also referred to in the context of FTAs and refer inter alia to the protection of labour rights such as the protection of freedom of association and collective bargaining. How do they do this? First, they base the sustainability standards they develop on existing international law by including references to international legal commitments in the foundational principles of VSS. Many of them refer explicitly to different ILO Conventions. Second, and importantly for the purpose of assessing compliance, they translate these principles in measurable indicators and action. In a third step, they develop a comprehensive institutional framework to monitor compli- ance with these standards including the provision of complaint mechanisms. These complaint mechanisms allow 'internal' participants (members of VSS organizations, VSS certificate holders, etc.) and 'external' stakeholders to raise issues relevant to the functioning of VSS including non-compliance with standards. Dispute settlement mechanisms provide a necessary complement to conformity assessment and auditing in order to foster compliance. Recently, one can observe the emergence of dispute settlement mechanisms in many VSS such as the Fair Wear Foundation and the Fair Labour Association. They take a variety of forms but several VSS allow external stakeholders (NGOs, citizens, etc.) to file a dispute if they believe that a violation of standards occurs. In order to enable stakeholders to raise a dispute, several VSS have also installed transparency measures through information disclosure procedures. Information disclosure procedures can inform different stakeholders on compliance with standards. Publicly available information in this context includes specific information about certification procedures, auditing reports, reports on violations, and reports on corrective action plans. This allows stakeholders to assess whether the reported information mirrors real conditions (Marx, 2014).

As noted above, some VSS have a complaint mechanism that allows for initiating a dispute in case of noncompliance with sustainable development provisions. This approach, which is a third-party to third-party system, could inspire the development of a dispute settlement mechanism for FTAs. The model of VSS targets companies more directly. If non-compliance is proven, a significant sanction is available in the form of annulation or suspension of a certificate which would influence market access in the importing country (Marx, 2014). Companies are key actors in the context of an FTA as well as for ensuring the implementation of labour standards, but they are not currently parties to the agreement. However, most violations with regard to the provisions contained in the TSD chapters are the result of companies' behaviour. Involving companies more directly in a FTA would imply a shared responsibility of states and firms to comply with the provisions in FTA labour chapters. Under this model, a dispute can be initiated by a range of third parties, sometimes including individual citizens. An equivalent in the context of FTAs would be to have a ban for specific products of specific companies in cases of repeated noncompliance by companies exporting products to the EU.

\section{Connecting the Dispute Settlement Mechanism of EU FTAs More Effectively to Existing Instruments}

\subsection{Connecting the Dispute Settlement Mechanism to the International Labour Rights System: The Case of the ILO Supervisory Mechanisms}

The inclusion of labour provisions in FTAs raises the question of how their coherence with the ILO's international

35 See e.g. art. 8.39 (6) CETA and art. 27 EUVFTA. 
labour rights system can be ensured. This question is all the more relevant given that most EU FTA labour provisions expressly refer to ILO instruments. Especially in recent EU FTAs, references are, unlike in their US counterparts, typically to the ILO's Fundamental Conventions rather than to only the ILO's Declaration on Fundamental Principles and Rights Work of 1998 (see ILO, 2013, p. 72, 2016, pp. 50-51). The interpretation and application of the relevant provisions can therefore directly rely on a body of guidelines elaborated by the relevant ILO quasijudicial bodies, which is not available for the ILO's 1998 Declaration. ${ }^{36}$ This opens several avenues for connecting the labour provisions of EU FTAs to the ILO's labour rights system.

The input by the ILO can, first and foremost, concern factual information on the situation of a particular country. In addition, legal guidance can be provided on the meaning of a particular convention as well as findings as to whether a given country is in compliance with the conventions it has ratified. This could, among others, be based on the reports of the ILO Committee of Experts on the Application of Conventions and Recommendations, which regularly reviews ILO member states' compliance with the conventions ratified by them, or the ILO's various submission-based procedures (AgustiPanareda, Ebert, \& Clercq, 2015, pp. 370, 372-373). ${ }^{37}$

Arguably, the most effective way to ensure consistency between the application of FTA labour provisions and the relevant ILO instruments would be to require the parties to a dispute or the panel itself to request the ILO's input, especially with regard to the interpretation of the provisions referencing ILO instruments. ${ }^{38}$ Such guidance could be sought by the parties at the consultation level as well as by the panel prior to delivering its report on the merits. Seeking such guidance by the panel should be mandatory rather than optional where labour provisions referring to ILO instruments are at stake. In the absence of a legally binding ruling of the International Court of Justice or of a specific (so far non-existent) ILO Tribunal on the matter at issue, ${ }^{39}$ the panel should consider the guidance emanating from the ILO as an authoritative treatment of the subject and only divert therefrom in exceptional circumstances and with justification.

One question arises as to which specific body of the ILO could provide such guidance. Given the specific mandate of existing supervisory bodies, their respective mandates may have to be extended if they were to provide the relevant guidance directly. Alternatively, the International Labour Office, the ILO's Secretariat, could compile relevant legal information, including, as the case may be, in consultation with relevant bodies. The Office could also offer technical assistance as well as carrying out advisory services to support the implementation of labour standards. Prospectively, the establishment of ad hoc committees by the ILO's Governing Body for the purpose of providing relevant interpretations could also be considered (Agusti-Panareda et al., 2015, pp. 370-371, 377). Putting in place a robust procedure regarding consultations with the ILO would not only be an important step towards avoiding further fragmentation of the international labour regime but could also increase the quality and legitimacy of the panel's reports.

\subsection{Connecting the Dispute Settlement Mechanism to Third Party Versus Third Party Mechanism: The Case of the OECD Guidelines for Multinational Enterprises}

The OECD Guidelines for Multinational Enterprises (Guidelines) provide institutional mechanisms for holding actors accountable in case of non-compliance with international standards, also referred to in FTA TSD chapters. The Guidelines are a set of recommendations addressed by participating governments to MNEs operating in or from their territory, on conduct relating, inter alia, to labour rights, environmental protection and human rights. As of November 2017, they were subscribed to by 48 states (all 35 OECD member states and 13 non-OECD members). All adhering states must establish a National Contact Point (NCP) at the domestic level to enhance the effectiveness of the Guidelines by promotional activities, the handling of enquiries and by 'contributing to the resolution of issues that arise relating to the implementation of the Guidelines in specific instances' (OECD, 2011, p. $68, \S 1)$.

Under this dispute resolution mechanism, any interested party may raise a 'specific instance' with an NCP when the party has evidence that an MNE is in noncompliance (domestically or abroad) with the Guidelines (OECD, 2011, p. 72, section C). The NCP deals with specific instances in three phases. ${ }^{40}$ In the first phase, the NCP conducts 'an initial assessment of whether the issues raised merit further examination', or should be dismissed (OECD, 2011, p. 72, section C $\$ 1$ ). Where a specific instance deserves 'further examination', the NCP is required, in a second phase, to 'discuss the issue further with the parties involved and offer 'good offices' with a view to facilitating the resolution of the problem' (OECD, 2011 , pp. $72-73, \S 2,83-84, \S 28)$. In the concluding third phase, the NCP makes the results of the mediation publicly available. If consensus is reached, it will issue a report stating that the parties have reached an agreement (OECD, 2011, p. 73, §3b). If consensus is not attained or if a party refuses to participate, the NCP has the authority to 'make recommendations on the implementation of the Guidelines as appropriate' (OECD, 2011, p. 73, §3c). A statement declaring that a given MNE has breached

\footnotetext{
36 The 1998 Declaration is only subject to a promotional follow-up (La Hovary, 2009, pp. 254-256).

37 The latter include representations to an ad hoc tripartite committee, complaints to be examined by an ad hoc commission of inquiry as well as a special procedure for freedom of association under which representations are examined by a standing tripartite committee (ILO, 2014, pp. 106-111).

38 In addition, the parties and the panel could of course consult the publicly available information made available on the ILO's website.

${ }^{39} \mathrm{Cf}$. art. 37 of the ILO Constitution.

40 In some cases, NCPs can also conduct research on their own motion without a specific complaint being filed.
} 
the Guidelines is, however, rarely issued in practice. The statement of conclusion constitutes the only 'sanctioning' mechanism that NCPs have at their disposal, as they lack authority to impose sanctions in the form of financial penalties, the suspension of licenses or the like (Davarnejad, 2011, p. 364). This mechanism is accordingly considered by some to be relatively weak (Fick Vendzules, 2010, p. 480), as it relies on MNEs to take voluntary corrective action, which does not always materialise in significant changes (Ruggie \& Nelson, 2015, p. 122).

The Guidelines and the NCPs could be connected to FTA labour provisions in various ways. First, the substance of the Guidelines could be linked to the FTA at issue. The most straightforward way to do this would consist of incorporating the content of the Guidelines into the FTA. This is possible since the adoption of the Guidelines is not restricted to OECD members, but is open to all states. Such incorporation of the Guidelines, in turn, would imply both a deepening and widening of the substantive provisions in the FTAs since the Guidelines cover substantive issues that are currently not covered in most FTA labour provisions, such as the obligation to provide certain information to employee representatives.

Second, and more importantly from a procedural perspective, wording could be included in the TSD chapter which requires the dispute settlement bodies established under the FTA (state-to-state or otherwise) to take into account the findings of the NCPs. This could provide additional leverage to the NCPs' determinations in case of established non-compliance with the Guidelines. At the same time, this would also help to ensure that the FTA labour provisions are applied in coherence with these Guidelines. Where the parties are not already adhering to the Guidelines, a provision could be inserted into the FTA to require the parties to adopt the Guidelines.

\section{Discussion}

This article started from the observation that most recent EU FTAs contain labour standards-related commitments whose enforcement mechanisms are, however, insufficient to have a significant impact in practice. This concerns especially the extant dispute settlement mechanisms. One way to think about how to address this concern is to look at existing mechanisms. While the instruments discussed in this article are not a panacea for labour standards protection, they may provide inspiration for rethinking existing approaches. In this regard, the article looked at five arrangements to identify key components for improving the current dispute settlement mechanism of EU FTA labour provisions.

The case of US FTAs provided insights into the value of complaint and sanction mechanisms. We argued, however, that to be effective such mechanisms need to come with direct access of stakeholders to dispute settlement, and we drew on the ICS to reflect on possible avenues for achieving this. Such a mechanism could also be comple- mented with a third party-third party dispute settlement component, as it exists under certain labour-related VSS. In a further step, we then examined options to better link dispute settlement mechanisms in EU FTA labour provisions to other related international arrangements of relevance to labour standards, namely the ILO supervisory mechanisms and the NCPs related to the OECD MNE Guidelines.

Integrating features of these different approaches, possibly in an entirely new model, arguably holds significant potential for enhancing the enforcement mechanisms of FTA labour provisions and, thereby, for ensuring that the relevant labour standards commitments do not remain empty promises in the books. It goes without saying that the mechanisms discussed above could not be harnessed for EU FTA labour provisions without the necessary adjustments. For example, the monetary compensation designed to compensate for individual economic damages under the investment court system may not be appropriate for labour standards violations where damages are much harder to quantify.

In the process of adapting these components, a few choices would need to be made, including the following. A first choice would be to decide who the target of a complaint should be: the state, an individual company or both. The case of the VSS discussed above offer ways to think about how companies might be targeted more directly. A second choice pertains to who has access to the complaint mechanisms. Does this remain a state-to-state affair, which is only accessible to the EU and other parties to the agreement, or will it provide access to a range of stakeholders who can pursue alleged breaches of the obligations contained in TSD chapters. A third choice concerns the use of sanctions as a measure of last resort, which could involve trade sanctions or other economic sanctions, such as fines. There is a need to reflect upon how these sanctions can be designed in a way that avoids disproportionate or otherwise undesirable effects, including relating to harm of vulnerable parts of the population or trade diversion.

Clearly, the implementation of a new model based on the components set out above would require significant political will by the trading partners concerned. It is worth highlighting, though, that all the elements discussed have already been tested in other fora. Given the current legitimacy crisis of economic globalization, the timing may be apposite for experimenting with innovative arrangements to ensure that FTAs are also socially beneficial.

\section{Acknowledgments}

This article is based on research conducted for the Ministry of Foreign Affairs of the Kingdom of the Netherlands. The authors thank the editors of the thematic issue and two reviewers for comments on a previous version of the article. All authors contributed to the introduction and conclusion. Axel Marx was lead author of the sections 
on the ILO, OECD and VSS while Franz Ebert drafted the sections on the EU and US FTA labour provisions. Nicolas Hachez drafted the section on investment arbitration.

\section{Conflict of Interests}

The authors declare no conflict of interests.

\section{References}

Acharya, A., \& Johnston, A. J. (2007). Comparing regional institutions. In A. Acharya \& A. J. Johnston (Eds), Crafting cooperation: The design and effectiveness of regional institutions (pp. 1-31). Cambridge, MA: Cambridge University Press.

Agusti-Panareda, J., Ebert, F., \& Clercq, D. (2015). ILO labor standards and trade agreements: A case for consistency. Comparative Labour Law and Policy Journal. Retrieved from http://heinonline.org/HOL/ LandingPage?handle=hein.journals/cllpj36\&div=30\& $\mathrm{id}=$ \&page $=$

Bartels, L. (2013). Human rights and sustainable development obligations in EU free trade agreements. Legal Issues of Economic Integration, 40, 297-313.

Campling, L., Harrison, J., Richardson, B., \& Smith, A. (2016). Working beyond the border? A new research agenda for the evaluation of labour standards EU trade agreements. International Labour Review, 155(3), 357-382.

Charnovitz, S. (2001). Rethinking WTO trade sanctions. American Journal of International Law, 95(4), 792-831.

Chayes, A., \& Handler Chayes, A. (1995). The new sovereignty: Compliance with international regulatory agreements. Cambridge, MA: Harvard University Press.

Cheong, D., \& Ebert, F. (2016). Labour law and trade policy: What implications for economic and human development? In S. Marshall \& C. Fenwick (Eds.), Labour regulation and development: Socio-legal perspectives (pp. 82-126). Cheltenham: Edward Elgar.

Choi, W.-M. (2007). The present and future of the investor-state dispute settlement paradigm. Journal of International Economic Law, 10(3), 725-747.

Compa, L., \& Brooks, T. (2015). NAFTA and the NAALC. Twenty years of North American trade-labour linkage. Alphen aan den Rijn: Kluwer.

Conceição-Heldt, E., \& Meunier, S. (2014). Speaking with a single voice: Internal cohesiveness and external effectiveness of the EU in global governance. Journal of European Public Policy, 21(7), 961-979.

Davarnejad, L. (2011). In the shadow of soft law: The handling of corporate social responsibility disputes under the OECD Guidelines for Multinational Enterprises. Journal of Dispute Resolution, 2, 351-385.

Davey, W. (2009). Compliance problems in WTO dispute settlement. Cornell International Law Journal, 42(1), 119-128.

Ebert, F. C. (2016). Labour provisions in EU trade agreements: What potential for channelling labour standards-related capacity building? International Labour Review, 155(3), 407-433.

Ebert, F. C. (2017). The Comprehensive Economic and Trade Agreement (CETA): Are existing arrangements sufficient to prevent adverse effects on labour standards? International Journal of Comparative Labour Law and Industrial Relations, 33(2), 295-330.

Fick Vendzules, S. (2010). The struggle for legitimacy in environmental standards systems: The OECD Guidelines for Multinational Enterprises. Columbia Journal of International Environmental Law and Policy, 21, 451-490.

Gött, H. (in press). An individual labour complaint procedure for workers, trade unions, employers and NGOs in future free trade agreements. In H. Gött (Ed.), Labour standards in international economic law. Berlin: Springer.

Harrison, J., Barbu, M., Campling, L., Richardson, B., \& Smith, A. (2017). Governing labour standards through free trade agreements: Limits of the European Union's trade and sustainable development chapters (Working paper on file with authors).

International Labour Organization. (2009). World of work report 2009. The global jobs crisis and beyond. Geneva: ILO. Retrieved from http://www.ilo.org/ wcmsp5/groups/public/@dgreports/@dcomm/docu ments/publication/wcms_118384.pdf

International Labour Organization. (2013). Social dimensions of free trade agreements. Geneva: ILO. Retrieved from http://www.ilo.org/wcmsp5/groups/ public/---dgreports/---inst/documents/publication/ wcms_228965.pdf

International Labour Organization. (2014). Rules of the game. A brief introduction to International Labour Standards (3rd ed.). Geneva: ILO. Retrieved from http://www.ilo.org/wcmsp5/groups/public/--ed_norm/---normes/documents/publication/wcms 318141.pdf

International Labour Organization. (2016). Assessment of labour provisions in trade and investment agreements. Geneva: ILO. Retrieved from http:// www.ilo.org/wcmsp5/groups/public/---dgreports/--inst/documents/publication/wcms_498944.pdf

Koh, H. (1997). Why do nations obey international law? Yale Law Journal, 108(8), 2599-2660.

La Hovary, C. (2009). Les droits fondamentaux au travail. Origines, statut et impact en droit international [Fundamental rights at work. Origins, status and impact in international law]. Paris: Presses Universitaires de France.

Lacy, D., \& Niou, E. M. S. (2004). A theory of economic sanctions and issue linkage: The roles of preferences, information, and threats. The Journal of Politics, 66(1), 25-42.

Linder, B., \& Steinkeller, A. (2013). The right to remedy: Extrajudicial complaint mechanisms for resolving conflicts of interest between business actors and 
those affected by their operations. Vienna: Ludwig Boltzmann Institute of Human Rights.

Marx, A. (2014). Legitimacy, institutional design and dispute settlement: The case of eco-certification systems. Globalizations, 11(3), 401-416.

Marx, A., Lein, B., \& Brando, N. (2016). The protection of labour rights in trade agreements: The case of the EU-Colombia agreement. Journal of World Trade, 50(4), 587-610.

Marx, A., \& Soares, J. (2015). Does integrating labour provisions in free trade agreements make a difference? An exploratory analysis of freedom of association and collective bargaining rights in $13 \mathrm{EU}$ trade partners. In J. Wouters, A. Marx, D. Geraets, \& B. Natens (Eds.), Global governance through trade (pp. 158-181). Cheltenham: Edward Elgar.

Niemann, A., \& Bretherton, C. (2013). EU external policy at the crossroads: The challenge of actorness and effectiveness. International Relations, 27(3), 261-275.

OECD. (2011). OECD guidelines for multinational enterprises 2011 edition. Paris: OECD.

OECD. (2012). Scoping paper for the public consultation on investor-state dispute settlement. Paris: OECD. Retrieved from www.oecd.org/dataoecd/61/ 29/50291642.pdf

Oehri, M. (2017). Civil society activism under US free trade agreements: The effects of actorness on decent work. Politics and Governance, 5(4), 40-48.

Orbie, J., \& Van den Putte, L. (2016). Labour rights in Peru and the EU trade agreement: Compliance with the commitments under the sustainable development chapter (OFSE Working Paper 58). Vienna: OFSE. Retrieved from https://www.econstor.eu/handle/ 10419/145974

Ostrom, E. (2005). Understanding institutional diversity. Princeton, NJ: Princeton University Press.

Postnikov, E., \& Bastiaens, I. (2014). Does dialogue work? The effectiveness of labor standards in EU preferential agreements. Journal of European Public Policy, 21(6), 923-940.

Ruggie, J., \& Nelson, T. (2015). Human rights and the OECD guidelines for multinational enterprises: Nor- mative innovations and implementation challenges. Brown Journal of World Affairs, 12(1), 99-127.

Sagar, J. V. (2004). The labor and environment chapters of the United States-Chile free trade agreement: An improvement over the weak enforcement provisions of the NAFTA side agreements on labor and the environment? Arizona Journal of International \& Comparative Law, 21(3), 913-949.

Scheuerman, W. E. (2001). False humanitarianism? US advocacy of transnational labour protections. Review of International Political Economy, 8(3), 359-388.

Schurtman, M. (2005). Los "Jonkeados" and the NAALC: The Autotrim/Customtrim case and its implications for submissions under the NAFTA labor side agreement. Arizona Journal of International \& Comparative Law, 22, 332-333.

Stoll, P.-T., Gött, H., \& Abel, P. (2017). Model labour chapter for EU trade agreements (Study Commissioned by the Friedrich-Ebert-Stiftung). Retrieved from http:// www.fes-asia.org/fileadmin/user_upload/documents /2017-06-Model_Labour_Chapter_DRAFT.pdf

United Nations Forum on Sustainability Standards. (2013). Voluntary sustainability standards. Today's landscape of issues and initiatives to achieve public policy objectives. New York, NY: United Nations Forum on Sustainability Standards. Retrieved from https://unfss.files.wordpress.com/2012/05/unfss-re port-initiatives-2_draft_lores.pdf

Van den Putte, L. (2015). Involving civil society in social clauses and the decent work agenda. Global Labour Journal, 6(2), 221-235.

Van Roozendaal, G. (2015). The diffusion of labour standards: The case of the US and Guatemala. Politics and Governance, 3(2), 18-33.

Van Schaik, L. (2013). EU effectiveness and unity in multilateral negotiations. Basingstoke: Palgrave Macmillan.

Vogt, J. S. (2015). The evolution of labor rights and trade-A transatlantic comparison and lessons for the Transatlantic Trade and Investment Partnership. Journal of International Economic Law, 18(4), 827-860.

\section{About the Authors}
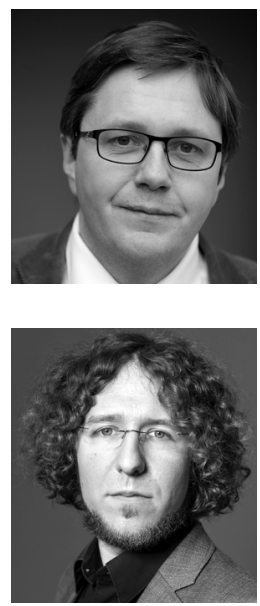

Axel Marx is deputy director of the Leuven Centre for Global Governance Studies, University of Leuven.

Franz Ebert is a Research Fellow at the Max Planck Institute for Comparative Public Law and International Law in Heidelberg. 


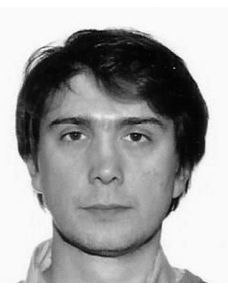

Nicolas Hachez is Lecturer in International and European Law at the KU Leuven Faculty of Law and in the KU Leuven Master of European Studies, and Senior Researcher at the Leuven Centre for Global Governance Studies. 